\title{
Preventing catastrophic climate change
}

\section{A review essay}

J B Foster and P Burkett (2017) Marx and the Earth: An anti-critique. Chicago: Haymarket Books

I Angus (2016) Facing the Anthropocene: Fossil capitalism and the crisis of the earth system. New York: Monthly Review Press

J W Moore (2015) Capitalism in the web of life: Ecology and the accumulation of capital. London: Verso

I Scoones, M Leach and P Newell (eds) (2015) The politics of green transformations. Abingdon: Routledge

I Gough (2017) Heat, greed and human need: Climate change, capitalism and sustainable wellbeing. Cheltenham: Edward Elgar.

D Helm (2017) Burn out: The end game for fossil fuels. New Haven: Yale University Press.

It seems almost tedious to repeat it but the key issue for the world today is how to prevent catastrophic climate change. Yet the analysis of the underlying causes of climate change remains undeveloped and strongly contested, the general public continues to be misinformed or uninformed and unengaged, and actions to mitigate climate change are mainly piecemeal, inadequate and ineffective. The international community has failed to provide sufficient protection for the global atmospheric commons, fossil-fuel 'business as usual' prevails (complete with subsidies from governments and the World Bank), and discredited market-based approaches persist. Blind faith is placed in technological innovation to save us all, and the need for a radical interpretation of the precautionary principle in the face of potential but multiply uncertain cataclysmic 'tipping points' goes unrecognised.

This essay focuses on what seems to me to be a key question, namely the contribution of capitalism to climate change and whether capitalism can or cannot be transformed so that disaster can be avoided. Foster, Burkett and Angus are all clear that capitalism is inherently destructive of the environment and must be replaced by socialism; Moore thinks capitalism cannot survive but is not clear about what, if anything, might take its place; Scoones et al contains a variety of views and approaches to political action, largely drawing upon a tradition of socio-technical transitions management; Gough emphasises governmental redistribution and changing consumption; and Helm basically argues that markets and competition states will solve the problem. Together, these books cover much of the spectrum of opinion on climate change, though not all of the issues associated with this topic. Ostensibly, they are all written for the general reader, but they convey very different theoretical and political messages: Foster and Burkett on the application of Marx's theory of value to ecology, Angus on the significance of the Anthropocene for the future of humanity, Moore on the concept of Capitalocene as a historically specific unity of humanity and nature, Scoones et al as an exposition of multiple possible and politically contested ways of moving from our unsustainable present to sustainable futures, Gough on the relevance of climate change for social inequality and social policy, and Helm on the issues for the energy industries and for economic and energy policy. The readership for Foster/Burkett, Angus and Moore is therefore mainly academic (though Angus is 
accessible to the lay reader and clearly aims to stimulate climate mitigation action), while the others are intended also to reach a wider audience, in particular energy policy communities (Scoones et al, Helm) and environmental and social policy makers and practitioners (Scoones et al, Gough), and are all written in accessible styles.

Readers of this journal will know that Marx saw capitalism as a mode of production whose products are commodities, which have both a concrete form (as useful goods or services, that is, use-value) and an abstract form (as exchange value or value). Commodity production involves a labour process, in which workers interact with nature (raw materials and means of production) to produce commodities. Nature is the source of many use-values, some of which enter into capitalist labour processes. Marx followed Adam Smith, however, in holding that human labour is the source of value under capitalism. All this is clearly set out in Foster and Burkett's book, especially pp 211-8, as part of a robust defence of Marx against those who claim that he was some kind of crude cornucopian who did not recognise the existence of ecological limits or that he made 'fatal' or 'serious' errors in his theory of value (as claimed by Walker, 2017: 54, 57; for more defence of Marx's theory of value, see Huber, 2017).

The crucial point for this review essay is the form of the interaction between humans and nature in specific production processes. Under capitalism, value becomes separated from use-value and takes on a life of its own, disconnected or abstracted from the natural processes of concrete reality. Cyclical processes of capital accumulation (M-C-M') tend to override natural cycles of carbon, nitrogen and phosphorus, with nature being appropriated as and when it is useful to do so in order to increase labour productivity and profitability (including when the appropriation is done for environmental ends - so-called 'green grabbing' - see Fairhead et al, 2012; McAfee, 2012). Marx originally noted this in connection with the failure of agricultural capitalists to recycle nutrients removed from the soil but the same pattern can be observed in all cases where nature's bounty is treated by capital as a 'free gift' or as what economists call 'externalities' (that is, as outside the attention of capitalists and their economic apologists). Such practices, seen as an unavoidable aspect of capitalist competition, result in metabolic or ecological rifts that tend to undermine the conditions for capitalist production itself (O'Connor, 1998, called this the second contradiction of capitalism).

Moore argues that the term 'metabolic shift' would be more appropriate. For him, 'it is not humanity's separation from Nature that matters' (Moore, 2015: 78) but the shift from one way of organising nature to another. For Marx, however, humanity's separation from nature is precisely what matters, and capitalism is much more than just a different way of organising nature. On the contrary: nature has its own ways of organising, which are being disrupted by capitalism. An important implication of Moore's argument is that modern history is understood primarily in terms of a search for 'cheap natures', with each period involving rising costs of material inputs to production until a crisis point is reached at which new modes of appropriation of nature emerge (Moore, 2015: 97-8, 227-8). Class struggle seems to be reduced to a dispute about which 'cheap natures' should be sought and how they should be appropriated - the concept of a metabolic or ecological rift seems to disappear.

Foster and Angus tend to equate capitalism's metabolic rift with the coming of the Anthropocene, with the Anthropocene being defined as a period of time 'when geological strata are dominated by remains of recent human origin' (Angus, 2016: 231). However, a metabolic rift has to do with the 
quality, not just the quantity, of such remains, so this term does not seem particularly useful for understanding 'the crisis of the earth system'- and is plagued with confusions and misconceptions, anyway (see Angus, 2016: 224-232). Consequently, Moore's term 'Capitalocene' seems preferable, because it names a period that coincides with the rise of a specific kind of social system (not human activity generally) that has changed the geology of our planet. There are problems with identifying exactly when the rise of capitalism resulted in this geological change (sometime between the $15^{\text {th }}$ century and the $19^{\text {th }}$ century) but it can be agreed that it has indeed occurred.

As is well known, Marx's theory of value holds that it is created by workers under conditions of capitalist production (that is, as propertyless wage-workers) and measured in terms of the amount of labour-time that is socially necessary for its production. Marx calls this measure 'abstract labour', which is essentially the equalisation of concrete acts of labour under the discipline of competition (Saad-Filho, 2002: 26-29), that is, within a capitalist labour-market. Further, workers are exploited to the extent that the value of what they produce exceeds the value of their hire, and this excess is crucial for capital accumulation. Moore (echoed by Walker, 2017) tries to extend the theory of value to include the appropriation of what he calls 'cheap natures', but this latter expression effectively obscures the distinction between nature as use-value and nature as value. For Moore, labour itself is just a 'cheap nature', even though for Marx it is the source of all value. For a neoclassical approach that reaches surprisingly similar conclusions to Moore's concerning capital's long-term reliance on 'relatively inexpensive fossil fuel resources', see Ayres and Voudouris (2014); for a critique of neoclassical understandings of value, see Huber (2017: 44); for the latest example of a longstanding failure to see that the law of value is specific to capitalism, see Walker (2017); and for the continuing failure of ecological economists to understand the difference between use-value and value, see Kallis' contribution to Kallis and Swyngedouw (2017, especially pp12 and 14).

The outstanding metabolic rift today is the disruption of the atmospheric carbon cycle due to the burning of fossil fuels and to methane emissions from livestock, resulting in the threat of catastrophic climate change. ${ }^{1}$ The key question addressed in the remainder of this paper is whether this excess of carbon emissions is necessary or contingent to capitalism as a mode of production that is, could these practices be terminated within capitalism or is it capitalism that has to be terminated? There appear to be five main and partially overlapping perspectives on this question:

1) Capital accumulation is seen as lying at the root of the problem because it inevitably increases energy use, which in turn tends to increase greenhouse gas emissions. In order to solve the problem, therefore, capitalism has to be overthrown or transformed or 'deaccumulated' (this is the view of eco-socialists such as Foster, Burkett and Angus - see also Clark and York, 2005; Huber, 2008, 2013; Lohmann, 2011; Smith, 2011; Schwartzman, 2012; Blauwhof, 2012; Klitgaard, 2013; Newell, 2015). A key feature of the eco-socialist argument is its emphasis on demilitarisation (see, for example, Angus, 2016, chapters 9 and 10), because of the huge (and insufficiently acknowledged) contribution of the military to GHG emissions.

2) Degrowth theory sees the problem as primarily one of over-production and/or over-consumption (Fournier, 2008; Latouche, 2009, 2010; Kallis, 2011, 2015; Kallis et al, 2012; Trainer, 2012; Muraca,

\footnotetext{
${ }^{1}$ Other important so-called 'planetary boundaries' (e.g. on water, phosphorus, nitrogen, aerosols, certain minerals, and biodiversity - Rockström et al, 2009) have also been transgressed or are at risk of being so, but these are not the focus of this essay.
} 
2013; Asara et al, 2015; Jackson, 2017; see also Cattaneo et al, 2012; and note Victor, 2012, on the political implausibility of a degrowth scenario). To solve the problem, consumption must be reduced to a level of 'sufficiency' (Lorek and Fuchs, 2013; Sekulova et al, 2013; Kallis, 2013).

3) Capitalism exists within a wider context of complex coupled human-environment systems that can be understood in a variety of ways that may enable the problem to be fixed - i.e. systems thinking approaches (Weinstein et al, 2013; Lorek and Spangenberg, 2014; García-Olivares and Solé, 2015), particularly from ecological economics (Klitgaard and Krall, 2012) or (following Harvey's concept of spatial fix) 'socio-ecological fixes' (McCarthy, 2015; Ekers and Prudham, 2017) or 'socio-ecological transformations' (Patterson et al, 2017). These are interesting arguments, which link with literature on governmentality (Lövbrand et al, 2009), but I do not have space to examine them here (though none of them addresses the issue of fixing the military).

4) Capitalism is a system that can be managed or redesigned or 'greened' so that disaster can be averted - the perspective of 'green growth' or 'green economy', i.e. green capitalism (the view of Helm - see also UNEP, 2011; Lawn, 2011; Mathews, 2011; Bowen and Fankhauser, 2011; Bina, 2013; Bowen and Hepburn, 2014: Smulders et al, 2014; Bailey and Preston, 2014; Wanner, 2015; Helm, 2016). This perspective (previously known as ecological modernisation) basically holds that decarbonisation can occur at a faster rate than capital accumulation (this is known, confusingly, as 'absolute decoupling' or 'strong sustainability'), thus enabling capitalism to survive. Unfortunately, however, there is no evidence that such decoupling has ever occurred, is occurring, or is likely to occur in the foreseeable future. Even Helm, a key prophet of the triumph of green capitalism, recognises that governments are captured by fossil-fuel interests (but does not seem to want to do anything about this), has no clear idea how gas (for example) is to be decarbonised in the short to medium term, and generally believes in salvation by new technology (for a more thoughtful approach to understanding green capitalism see Knuth, 2017).

5) Capitalism can be tamed or humanised through the provision and fair distribution of social welfare (the view of Gough - see also van den Burgh, 2011; Gomez-Baggethun and Naredo, 2015; Capellán-Pérez et al, 2015 - how reduced consumption in developed countries could be welfareenhancing) and economic democracy (Johanisova and Wolf, 2012). This approach seems to involve an element of degrowth as well as redistribution but it emphasises concerted action by benevolent 'environmental states' or 'climate states' (Gough, 2017: 121), which do not actually exist. Gough offers a plethora of interesting policy proposals but no clear pathways for implementing them, much important criticism of the harms arising from green growth but no clear analysis of how capitalism produces such harms, and, despite a chapter entitled 'Decarbonising the economy', no clear approach to the decarbonisation of energy or production.

For the purposes of this essay, the problem with the degrowth theorists and environmental statists is that they do not engage with Marx's theory of capital and lack a clear vision of the extent to which capitalism needs to be changed if we are to survive on this planet (Foster, 2011; see Schwartzman, 2012 , for other problems with the work of degrowth advocates). Granted, degrowth is consciously opposed to capital growth and to some extent necessary (particularly in developed countries) in order to avoid globally catastrophic climate change, but its proponents do not sufficiently recognise that growth is merely a symptom of the underlying problem with capitalism, namely its tendency to metabolic rift. Degrowth theorists also often fail to distinguish consistently between the growth of 
value (as expressed, for example, in GDP) and the growth of use-value (the quantity and quality of goods and services being produced), which leads them to miss the complexity of the relationship between the two. An exception here is Sorman and Giampietro (2013), who focus on the social metabolism of energy and conclude that degrowth (of use-value) is inevitable as increasing amounts of energy (whether renewable or not) are required to generate and distribute energy - that is, a declining rate of energy return on energy invested (EROEI) (as fossil fuels become more difficult to extract and renewables continue to have lower energy output per input). In value terms, this is analogous to Marx's law of the falling rate of profit but, whereas historically the latter has been counteracted by technical innovation and the emergence of new markets (resulting in increased labour productivity and lower production costs), currently there has been little evidence of even a slowing down in the decline of EROEI. This decline then has implications for capitalist production in terms of reduced capacity for productivity increase resulting in reinforcement of the tendency towards profitability decline and more serious economic-ecological crisis (see also García-Olivares and Ballabrera-Poy, 2015: 594-6, who argue, in total contradiction of Helm, that on this basis we must now plan for a steady-state economy). This argument relating to the technical composition of capital holds irrespective of what happens to the value composition of capital, which may either rise or fall or both. It is therefore no exaggeration to say that the future of capitalism rests ultimately on the scope for appropriate technological innovation.

This could perhaps help to explain why the literature on climate change is dominated by technocratic approaches (e.g. the 'multi-level perspective' and transitions management), which see the problem of reducing GHG emissions as primarily one of engineering a shift from one 'socio-technical regime' to another, particularly with respect to energy generation. Economics, and even politics (usually understood in technocratic terms as 'governance' - e.g. Biermann et al, 2009), have been recognised as important, but only as additional factors to be entered into the technical calculations and models (Newell, 2015; for a useful if partial review see Schmitz, 2015). So-called 'Integrated Assessment Models' (IAMs), integrating physical and economic models, seem to be the holy grail here but they have not been shown to be any more reliable than long-range weather forecasting (and viewed as 'close to useless' by Pindyck, 2013, cited in Farmer et al, 2015: 347). Increasingly sophisticated scenarios have been developed (e.g. the transition pathways to low carbon electricity in the UKRTP Engine Room, 2015; Chilvers et al, 2017; Barton et al, 2018) but still with implausible and unrealistic or inappropriate economic and technical assumptions (for example, that carbon capture and storage will be economically viable, that biomass and bioenergy will be carbon-neutral, that combined heat and power will expand significantly in the near future, that fuel prices will stabilise or not) and little attention to the overwhelming need for immediate and decisive action. It appears, then, that technocratic approaches have not worked very well so far, prompting some of their promoters to consider the nature of political power more seriously, though not to the extent of addressing Marxist arguments (see, for example, Geels, 2014). It could well be the case, however, that appropriate technical change is not always possible within capitalism because the application of new technology itself requires additional inputs of energy and new materials, which in turn require to be generated, extracted and manufactured (which, in turn, involves continued harmful exploitation of labour - for examples, see Newell, 2015: 77) - a case, perhaps, not of a circular economy or dematerialisation but of self-destructing Ouroboros.

To end this review on a positive note, Newell argues that, despite a widespread but misplaced faith in technological innovation and despite the on-going lock-in of fossil-fuel capitalism, 'there is 
significant movement from below' (Newell, 2015: 82) for a low-carbon future, which can succeed so long as it focuses 'on the terrain of the here and now and the actually existing political economy, as it is, not as we would like it to be' (Newell, 2015: 84). Caution is required, however, because movements from below are not necessarily progressive (a distinction that is obscured by the use of the term 'grassroots' - Smith and Ely, 2015). Schmitz (2015) suggests that a more open and inclusive political approach is needed, especially given the urgency of the timescale now, and the Citizens Climate Lobby (https://citizensclimatelobby.org ) seems to me an example of such an approach. It is becoming increasingly clear, as 'the Great Acceleration' (Steffen et al, 2011: 618) progresses, that the Capitalocene period is associated with a set of epochal ecological rifts, which can be repaired only by means of a global eco-social transformation that permanently restores a metabolic balance between humanity and nature. This transformation will involve the politicised and systematic application of the precautionary principle (Burkett, 2016), processes of demilitarisation, solarisation and agro-ecology (Schwartzman, 2012: 119,124), and maximising the extent to which the socialisation of capitalism can at the same time facilitate living within our planetary boundaries. The alternatives are ecological collapse, as global temperatures soar way above what is humanly bearable, and/or economic ruin, as sources of energy become increasingly less exploitable.

\section{References}

Asara, V., Otero, I., Demaria, F. and Corbera, E. (2015) 'Socially sustainable degrowth as a socialecological transformation: repoliticizing sustainability', Sustainability Science 10: 375-384.

Ayres, R. and Voudouris, V. (2014) 'The economic growth enigma: capital, labour and useful energy?' Energy Policy 64: 16-28.

Bailey, R. and Preston, F. (2014) Stuck in transition: Managing the political economy of low-carbon development. London: Chatham House (the Royal Institute of International Affairs). www.chathamhouse.org.

Barton, J., Davies, L., Dooley, B., Foxon, R., Galloway, S., Hammond, G., O’Grady, A., Robertson, E. and Thomson, M. (2018) 'Transition pathways for a UK low-carbon electricity system: comparing scenarios and technology implications', Renewable and Sustainable Energy Reviews 82: 2779-2790.

Biermann, F., Betsill, M., Gupta, J., Kanie, N., Lebel, L., Liverman, D., Schroeder, H., Siebenhüner, B., Conca, K., da Costa Ferreira, L., Desai, B., Tay, S., Zondervan, R. (2009) Earth system governance: People, places and the planet. Science and implementation plan of the Earth system governance project. Earth System Governance Report 1, IHDP Report 20. Bonn: The Earth System Governance Project, IHDP.

Bina, O. (2013) 'The green economy and sustainable development: an uneasy balance?' Environment and Planning C: Government and Policy 31: 1023-1047.

Blauwhof, F. (2012) 'Overcoming accumulation: is a capitalist steady-state economy possible?' Ecological Economics 84: 254-261.

Bowen, A. and Fankhauser, S. (2011) 'The green growth narrative: paradigm shift or just spin?' Global Environmental Change 21: 1157-1159. 
Bowen, A. and Hepburn, C. (2014) 'Green growth: an assessment', Oxford Review of Economic Policy 30, 3: 407-422.

Burkett, P. (2016) 'On eco-revolutionary prudence: capitalism, communism, and the precautionary principle', Socialism and Democracy 30, 2: 73-96.

Capellán-Pérez, I., Mediavilla, M., de Castro, C., Carpintero, O. and Miguel, L. J. (2015) ‘More growth? An unfeasible option to overcome critical energy constraints and climate change', Sustainability Science 10: 397-411.

Cattaneo, C., D’Alisa, G., Kallis, G., Zografos, C. (2012) ‘Degrowth futures and democracy', Futures 44: 515-523.

Chilvers, J., Foxon, T., Galloway, S., Hammond, G., Infield, D., Leach, M., Pearson, P., Strachan, N., Strbac, G. and Thomson, M. (2017) 'Realising transition pathways for a more electric, low-carbon energy system in the United Kingdom: challenges, insights and opportunities', Proceedings of the Institution of Mechanical Engineers Part A: J Power and Energy. doi: 10.1177/0957650917695448.

Clark, B. and York, R. (2005) 'Carbon metabolism, global capitalism, and the biospheric rift', Theory and Society 34, 4: 391-428.

Ekers, M. and Prudham, S. (2017) 'The metabolism of socioecological fixes: capital switching, spatial fixes, and the production of nature', Annals of the American Association of Geographers 107, 6: 1370-1388.

Fairhead, J., Leach, M. and Scoones, I. (2012) 'Green grabbing: a new appropriation of nature?' The Journal of Peasant Studies 39, 2: 237-261.

Farmer, J. D., Hepburn, C., Mealy, P. and Teytelboym, A. (2015) 'A third wave in the economics of climate change', Environmental Resource Economics 62: 329-357.

Foster, J. B. (2011) 'Capitalism and degrowth: an impossibility theorem', Monthly Review 62: 26-33.

Fournier, V. (2008) 'Escaping from the economy: the politics of degrowth', International Journal of Sociology and Social Policy 28, 11/12: 528-545.

García-Olivares, A. and Ballabrera-Poy, J. (2015) 'Energy and mineral peaks, and a future steady state economy', Technological Forecasting \& Social Change 90: 587-598.

García-Olivares, A. and Solé, J. (2015) 'End of growth and the structural instability of capitalism from capitalism to a Symbiotic Economy', Futures 68: 31-43.

Geels, F. (2014) 'Regime resistance against low-carbon transitions: introducing politics and power into the multi-level perspective', Theory Culture \& Society 31, 5: 21-40.

Gomez-Baggethun, E. and Naredo, J. M. (2015) 'In search of lost time: the rise and fall of limits to growth in international sustainability policy', Sustainability Science 10: 385-395.

Helm, D. (2016) 'The future of fossil fuels - is it the end?' Oxford Review of Economic Policy 32, 2: 191-205. 
Huber, M. (2008) 'Energizing historical materialism: fossil fuels, space and the capitalist mode of production', Geoforum 40: 105-115.

Huber, M. (2013) Lifeblood: Oil, freedom, and the forces of capital. Minneapolis: University of Minnesota Press.

Huber, M. (2017) 'Value, nature, and labor: a defense of Marx', Capitalism Nature Socialism 28, 1: 39-52.

Jackson, T. (2017) Prosperity without growth: Foundations for the economy of tomorrow. $2^{\text {nd }}$ ed. Abingdon: Routledge.

Johanisova, N. and Wolf, S. (2012) 'Economic democracy: a path for the future?' Futures 44: 562570 .

Kallis, G. (2011) ‘In defence of degrowth’, Ecological Economics 70: 873-880.

Kallis, G. (2013) 'Societal metabolism, working hours and degrowth: a comment on Sorman and Giampietro', Journal of Cleaner Production 38: 94-98.

Kallis, G. (2015) 'The degrowth alternative', Great Transition Initiative (February 2015).

Kallis, G., Kerschner, C. and Martinez-Alier, J. (2012) 'The economics of degrowth', Ecological Economics 84: 172-180.

Kallis, G. and Swyngedouw, E. (2017) 'Do bees produce value? A conversation between an ecological economist and a Marxist geographer', Capitalism Nature Socialism, DOI:

10.1080/10455752.2017.1315830

Klitgaard, K. (2013) 'Heterodox political economy and the degrowth perspective', Sustainability 5: 276-297.

Klitgaard, K. and Krall, L. (2012) 'Ecological economics, degrowth, and institutional change', Ecological Economics 84: 247-253.

Knuth, S. (2017) 'Green devaluation: disruption, divestment, and decommodification for a green economy', Capitalism Nature Socialism 28, 1: 98-117.

Latouche, S. (2009) Farewell to growth. Cambridge: Polity Press.

Latouche, S. (2010) 'Degrowth', Journal of Cleaner Production 18: 519-522.

Lawn, P. (2011) 'Is steady-state capitalism viable? A review of the issues and an answer in the affirmative', Annals of the New York Academy of Sciences 1219: 1-25.

Lohmann, L. (2011) 'Capital and climate change', Development and Change 42, 2: 649-668.

Lorek, S. and Fuchs, D. (2013) 'Strong sustainable consumption governance - precondition for a degrowth path?' Journal of Cleaner Production 38: 36-43. 
Lorek, S. and Spangenberg, J. (2014) 'Sustainable consumption within a sustainable economy beyond green growth and green economies', Journal of Cleaner Production 63: 33-44.

Lövbrand, E., Stripple, J. and Wiman, B. (2009) 'Earth System governmentality: reflections on science in the Anthropocene', Global Environmental Change 19: 7-13.

Mathews, J. (2011) 'Naturalizing capitalism: the next Great Transformation', Futures 43: 868-879.

McAfee, K. (2012) 'The contradictory logic of global ecosystem services markets', Development and Change 43, 1: 105-131.

McCarthy, J. (2015) 'A socioecological fix to capitalist crisis and climate change? The possibilities and limits of renewable energy', Environment and Planning A 47: 2485-2502.

Muraca, B. (2013) 'Décroissance: a project for a radical transformation of society', Environmental Values 22, 2: 147-169.

Newell, P. (2015) 'The politics of green transformations in capitalism', in Scoones et al: 68-85.

O'Connor, J. (1998) Natural Causes. New York: Guilford.

Patterson, J., Schulz, K., Vervoort, J., van der Hel, S., Widerberg, O., Adler, C., Hurlbert, M., Anderton, K., Sethi, M. Barau, A. (2017) 'Exploring the governance and politics of transformations towards sustainability', Environmental Innovation and Societal Transitions 24: 1-16.

Pindyck, R. S. (2013) 'Climate change policy: what do the models tell us?' Journal of Economic Lit 51, 3: 860-872.

Realising Transition Pathways Engine Room (2015) Distributing power: A transition to a civic energy future. Realising Transition Pathways Research Consortium.

Rockström, J., Steffen, W., Noone, K., Persson, A., Chapin, F., Lambin, E., Lenton, T., et al (2009) 'Planetary boundaries: exploring the safe operating space for humanity', Ecology and Society 14, 2: 32

Saad-Filho, A. (2002) The value of Marx. London: Routledge.

Schmitz, H. (2015) ‘Green transformation: is there a fast track?’ in Scoones et al: 170-184.

Schwartzman, D. (2012) 'A critique of degrowth and its politics', Capitalism Nature Socialism 23, 1: 119-125.

Sekulova, F., Kallis, G., Rodríguez-Labajos, B. and Schneider, F. (2013) 'Degrowth: from theory to practice', Journal of Cleaner Production 38: 1-6.

Smith, A. and Ely, A. (2015) 'Green transformations from below? The politics of grassroots innovation', in Scoones et al: 102-118.

Smith, R. (2011) 'Green capitalism: the god that failed', Real-World Economics Review 56. www.paecon.net/PAEReview/issue56/Smith56.pdf. 
Smulders, S., Torman, M. and Withagen, C. (2014) 'Growth theory and "green growth", Oxford Review of Economic Policy 30, 3: 423-446.

Sorman, A. and Giampietro, M. (2013) 'The energetic metabolism of societies and the degrowth paradigm: analysing biophysical constraints and realities', Journal of Cleaner Production 38: 80-93.

Steffen, W., Crutzen, P. and McNeill, J. (2011) 'The Anthropocene: are humans now overwhelming the great forces of nature?' AMBIO: A Journal of the Human Environment 38, 8: 614-621.

Trainer, T. (2012) ‘De-growth: do you realise what it means?' Futures 44: 590-599.

United Nations Environment Programme (UNEP) (2011) Green economy: Pathways to sustainable development and poverty eradication. www.unep.org/greeneconomy.

van den Bergh, J. (2011) 'Environment versus growth - a criticism of "degrowth" and a plea for "agrowth", Ecological Economics 70: 881-890.

Victor, P. (2012) 'Growth, degrowth and climate change: a scenario analysis', Ecological Economics 84: 206-212.

Walker, R. (2017) 'Value and nature: rethinking capitalist exploitation and expansion', Capitalism Nature Socialism 28, 1: 53-61.

Wanner, T. (2015) 'The new "passive revolution" of the green economy and growth discourse: maintaining the "sustainable development" of neoliberal capitalism", New Political Economy 20, 1: 21-41.

Weinstein, M., Turner, R. E. and Ibáñez, C. (2013) 'The global sustainability transition: it is more than changing light bulbs', Sustainability: Science, Practice, \& Policy 9, 1: 4-15. 